\title{
REVIEWS
}

\section{Molecular Mechanisms of Telomerase Activity Regulation}

\author{
L.V. Porubleva \\ Institute of Molecular Biology and Genetics, NAS of Ukraine \\ 150, Acad. Zabolotny Str., Kyiv, 03143, Ukraine \\ polary_3@mail.ru
}

\begin{abstract}
Telomerase is a special ribonucleoprotein complex that synthesize telomeres found at the ends of linear chromosomes and are essential for maintaining chromosome stability and integrity. Telomerase is active in stem cells and almost not detected in somatic cells. Its activity is cell cycle dependent, strongly regulated during cell differentiation, and highly correlated with proliferative capacity of cells. In addition, telomerase is regulated to provide telomere length homeostasis in telomerase-positive cells of germ lines. The recent studies of global gene expression changes in telomere and telomerase mutants provide the evidence that molecular mechanisms of telomerase regulation are very complicated, multilevel, interconnected, and highly coordinated. The aim of this review is to present current data regarding regulation of telomerase maintenance of telomeres during cell cycle and differentiation as well as molecular mechanisms of telomere length homeostasis in humans and some other organisms.
\end{abstract}

Keywords: telomerase, telomere, regulatory mechanisms, differentiation, cell cycle, proliferative capacity, homeostasis.

Introduction. The first evidence of reparation of ends of eukaryotic chromosomes was obtained by B. McClintock in 1939 [1], who noticed the capability of corn embryonic cells to "cure" the broken chromosome ends and the absence of such feature in endosperm cells. At the same time aforementioned difference in these types of cells surprised her, however, no explanation followed. The discovery of the mechanism of DNA replication gave rise to a problem of end underreplication, connected with the capability of DNA-polymerase to synthesize 5'-end of linear DNA, which would result in the loss of genetic information on the chromosome ends [2]. In 1971, A.M.Olovnikov proposed the possible structure of the ends of linear DNA as "non-information gene of "buffer" function

(C).V. PORUBLEVA, 2006 and monotonous nucleotide sequence", which shortened gradually during mitosis and protected the information genes from losses as a result of underreplication [2], he also foresaw the existence of special mechanism of synthesis of the mentioned end DNA in tumour, germinal cells, and some other kinds of cells, capable of endless cell division. The first evidence to prove his hypothesis was obtained in 1978 by E.H.Blackburn and J.Gull, who cloned telomere from the simplest Tetrahymena thermophila [3]. It was simple G-rich uncoded structure TTGGGG, which was repeated numerous times. And then in 1985, Blackburn discovered the mechanism of telomeric repeat synthesis using telomere terminal transferase or telomerase [4].

Since the time of its discovery, telomerase activity was shown to correlate with differentiation state as well 
as proliferative capacity of the cells. Active telomerase is detected in stem cells, it is practically absent in somatic cells and is activated at early stages of dedifferentiation and proceeding to non-controllable proliferation in cancer and in immortalized cell lines [5]. The inactivation of telomerase results in successive shortening of telomere, ageing of cells, and apoptosis. However, in numerous cases of cancer at high level of telomerase activity, the telomeres are shortened to the length, which is shorter than the critical one, but the cell continues its division. Besides, the inhibition of telomerase increases the risk of tumour formation in rapidly regenerating tissues of humans and mice.

Due to the role of telomerase in the processes of ageing and tumor progression it became the object of deep and comprehensive study in many laboratories of the world. At present significant bulk of knowledge on functions and inhibitions of telomerase in humans, mice, yeasts, protozoa and in cell cultures has been collected. Although, a great number of reviews are dedicated to the regulation of telomerase activity (e.g. [5-24]), the recent results about global change in gene expression in telomerase mutants, which provide additional information regarding the mechanisms of regulation of telomerase activity were obtained.

Telomere as telomerase substrate The main telomerase function is the synthesis of telomeric repeats. It determines the role of telomerase for cells. Therefore, some attention to telomeres has to be paid but the detailed analysis of structure and functions of telomeres is not the purpose of this review. Several nice reviews dedicated to telomeres have been already published recently [25-27]. Telomere is a specific DNA-protein complex which provides complete replication of terminal DNA and protects linear ends of eukaryotic chromosomes from cross-linking, degradation, recombination, and their recognition as double-stranded breaks by the reparatory system of a cell, i.e. stabilizing the chromosomal apparatus in such a way $[25,28,29]$. Telomeric DNA is a tandem repeat of TTAGGG hexamer in mammalians [7] and TTTAGGG heptamer in plants [30] and irregular repeats TT(G)1-3 in yeasts [31]. Another model organism Drosophila melanogaster and some plants do not have typical telomeric repeats [32-34]. On 3'-end of telomeric DNA of mammalians and plants there is a specific single-stranded G-rich overhang, which bending back forms so called T-loop (telomeric loop) [35]. Its hybridization with anti-parallel strand of partially untwisted telomeric DNA duplex generates D-loop (D-displacement). Some convincing evidences on G-rich overhang playing an important role in telomere functioning as a substrate for binding of specific DNA-binding proteins which protect the ends of chromosomes from degradation and cross-linking have recently appeared [36, 37]. Moreover, G-rich overhang is necessary as a substrate for telomerase which is incapable of extending double-stranded DNA [38].

The bulk of telomeric DNA is organized into nucleosomes. However the special nucleotide sequence of telomeric DNA defines binding of the specific telomeric proteins to its terminal region [26]. Moreover, the protein components provide telomeres with their basic features [27]. Telomere-binding proteins form specific telomeric heterochromatin which protects the ends of chromosomes and inhibits the expression of telomeric and subtelomeric genes as well as genes nearest to them, determining, so called telomeric positive effect [40]. Telomeric heterochromatin was shown to have common features with the centromeric one. histone proteins of telomeric heterochromatin are able to be methylated, which changes the telomere state and consequently the telomerase access to them, performing the epigenetic regulation of telomere length [41, 42].

The proteins associated with telomeres determine telomeric spatial structure. Telomeric Repeat Binding Factor 1 (TRF1) associated with double helix of human telomere bends telomeric DNA, and therefore causes the formation of T-loop [39]. TRF1 concentration is correlated with the length of telomere and, as it has been recently stated, transmits the information about the length and the state of double helical telomere to POT1 (Protection of Telomeres) protein, localized on single helix G-rich overhang. Its basic functions are protection of telomeres and the regulation of their length [43]. One more protein associated with single strand G-rich overhang is TRF2, which stabilizes T-loop and prevents telomere cross-linking [37]. T- and D-loops formation has been recently determined to be the main way of protecting chromosome ends. [44].

The length of telomeres varies significantly in different organisms, in different species of every genus 
Dependence of telomere length and proliferative capacity of human cells on telomerase activity

\begin{tabular}{|c|c|c|c|c|}
\hline $\begin{array}{c}\text { Telomerase } \\
\text { activity }\end{array}$ & Type of cells & Length of telomeres & Number of cell divisions & Reference \\
\hline- & $\begin{array}{l}\text { Mutant (knock-out or hTR } \\
\text { destabilisation) }\end{array}$ & Short & Ability to endless division & [39-41] \\
\hline- & Somatic cells & Normal (gradual shortening) & $50-100$ & {$[7]$} \\
\hline+ & Stem cells & $\begin{array}{l}\text { Normal (slow shortening, except for } \\
\text { germ line cells) }\end{array}$ & Ability to endless division & {$[7]$} \\
\hline+++ & Tumor (benign/malignant) cells & $\begin{array}{l}\text { Varies (but the most often is shorter } \\
\text { than critical length) }\end{array}$ & Endless & {$[36,43]$} \\
\hline+++++ & $\begin{array}{l}\text { Cell fraction in the immortalized } \\
\text { cell culture }\end{array}$ & $\begin{array}{l}\text { Does not differ from immortalized } \\
\text { telomeres length }\end{array}$ & $\begin{array}{l}\text { Has not been reported (cell } \\
\text { ageing signs present) }\end{array}$ & [44-46] \\
\hline
\end{tabular}

population, in different cells of organism, in different chromosomes of the same cell, and even on different chromosome arms [45]. In the somatic cells of multicellular organisms, where telomere synthesis does not occur, they are shortened for 50-200 nucleotides as a result of underreplication during each cell division [46] until the length of telomere reaches its critical value and telomere is incapable of fulfilling its function. The mechanisms which lead the cell to replicative ageing, i.e. the cell becomes indivisible or the apoptosis is launched, are activated as a result of underreplication at the length value smaller than the critical one or in case of loss of telomere function due to injury. The apoptosis was shown to be launched by the smallest telomere [47, 48]. If it does not happen for some reasons and the cell with defective telomeres continues to divide, it results in genomic instability and, probably, in malignant transformation of the cell [49]. Therefore, for some time the telomeres were considered to be a kind of "biological clocks", which determine duration of lifespan of cells and, possibly, of entire organism. However, the numerous recent data, testify about the complete miscorrelation between the length of telomere and the life of the cell and the organism [50], i.e. the telomeres can not be the "clockwork" counting out the lifetime of cell and, moreover, the organism, nevertheless, undoubtedly they can be considered a rather governing gear in such "clockwork", the correlation of which with its other constituents remains unclear.

Telomerase synthesis - the main mechanism of telomeric repeats replenishment. The main factor in providing intact telomeres is the synthesis of telomeric repeats by the telomerase. Replenishing telomeric repeats, the telomerase maintains constant cell division, and therefore, it can be considered as the marker of proliferative capacity of cells (Table).

Telomerase is unique ribonucleoprotein the basic components of which are RNA-subunit (TR Telomerase RNA), containing matrix area, which is complementary to telomeric repeat of G-rich chain, and the protein subunit which is reverse transcriptase (TERT - Telomerase Reverse Transcriptase), capable of synthesizing 5'-3'-telomeric DNA-chain (G-rich), using its own RNA as a matrix [51]. Telomerase reverse transcriptases are characterized by high homology levels in comparison to other reverse transcriptases. They have seven conservative motives of reverse transcriptase sequences [52]. Nevertheless, telomerase catalytic subunits have unique $\mathrm{C}$ - and N-terminal sequences, which perform specific telomerase functions, contrary to "ordinary" reverse transcriptases $[9,52]$. N-terminal site sequence of TERT binds to telomerase RNA as well as with other components of telomerase holocomplex, i.e. performing multimerisation in such a way $[53,54]$. C-terminal site binds telomerase to telomere and together with $\mathrm{N}$-end are responsible for its localization in the nucleolus [55].

Unlike conservative catalytic subunit, telomerase RNA-subunit of different organisms is variable in both size and sequence [56]. Phylogenetic analysis of RNA-subunits of different organisms showed that regardless of significant heterogeneity of primary TR sequences, their secondary structures are rather 


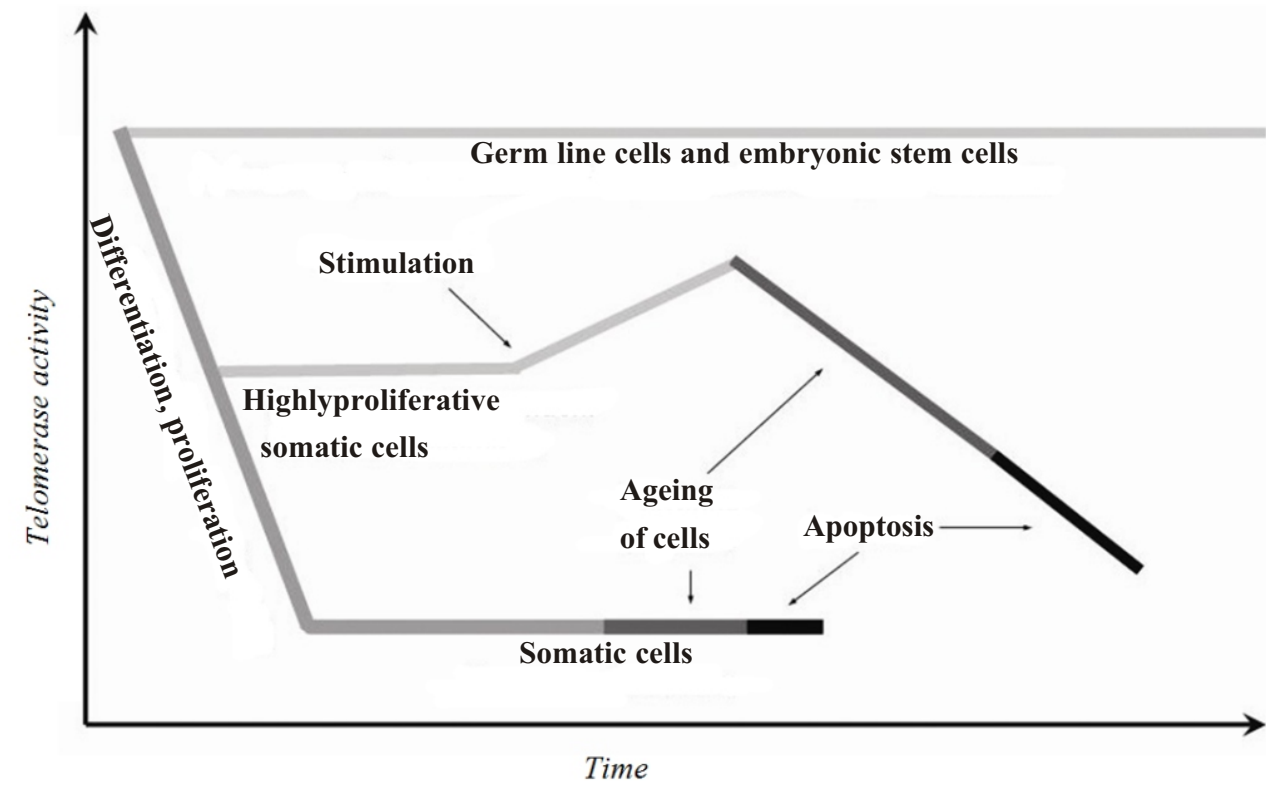

Fig.1. Dependence of telomerase activity on the differentiation state of human cells

conservative [57]. It may be explained by conservative catalytic subunits requiring the same conservatism in the structure of other telomerase components, and, as it was supposed earlier, the active centre, which ensures the telomerase activity, is of similar 3D structure in different organisms [5]. Though only TR and TERT are necessary for telomerase activity reconstruction in vitro [58], isolated catalytically active telomerase contains some protein components (besides TR and TERT) which are considered to be necessary for correct operation of telomere in vivo [59]. Telomerase Protein (TEP1), associated to TR, is a part of human telomerase complex [60]. The role of this protein for telomerase has not been studied yet. It is interesting that TEP1 knockout is reflected neither on telomerase activity nor telomere length, but it does accelerate ageing. The other telomerase components are the molecular chaperones p23 and HSP90 [61], the basic function of which is collecting telomerase holoenzyme and maintaining its stability. They are constantly bound to telomerase complex which may testify about its accumulation in the nucleus and not cytoplasm.

Dependence of telomerase activity on cell differentiation state Telomerase activity in unicellular organisms is cell cycle regulated and depends on the intensity of cell proliferation providing homeostasis of telomere length. Regulation of telomarase activity in multicellular organisms is supposed to be much more complicated. It correlates tightly with proliferative potential of cells (Fig. 1, Table) and changes in the process of the organism's development depending on the type of cell differentiation (for detailed review of telomerase tissue-specific activity see ref.[6]).

Telomerase activity in humans is detected at the blastocyst stage with subsequent disappearing in the majority of embryonic tissues in 20 weeks of embryo development [62]. Telomerase activity disappears at earlier stages in brain, bones, heart, and kidney cells and later - in muscles, liver, lungs and spleen cells. In germ line cells that keep on dividing in the course of their lifetime, telomerase synthesis of telomeres is controlled maintaining the length of the latter at the constant level. In mature spermatozoa and ovocytes incapable of dividing anymore, telomerase is inactive, which correlates with the long time of these cells being in quiescence [62].

Telomerase activity is not detected in adult somatic cells with limited capability of dividing. Contrary to the majority of somatic cells of human adult, where telomerase is repressed completely, some stem cells and stem-like cells (bone marrow cells, cells belonging to hematopoetic and immune systems, basal keratinocites and intestine crypt cells) reveal insignificant level of telomerase activity after being stimulated for division [6]. This telomerase activity 
level is enough for duration of replicative cell lifetime. However, they were observed to have the shortening of telomerase length with age, though it was a significantly slower process than in comparison to other somatic cells.

Similar distribution of telomerase activity occurs in plants, regardless of a series of specific features of their development, namely, late germ line formation, totipotency of plant cells (i.e. ability of plant cells to differentiate into any other type of cells), ability to vegetative reproduction, and virtually unlimited growth of some plant species. Telomerase is active in stem cells of apical meristem, in germ line cells and is inactive in somatic cells [63].

Therefore, contrary to unicellular eukaryotes, where telomerase activity is regulated only in the course of cell cycle, several ways of telomerase activity regulation depending on type of cells and their proliferative capacity may be distinguished in multicellular organisms:

-telomerase activity regulation in

telomerase-positive cells during cell cycle;

-flexible telomerase activity regulation in germ line cells in order to provide homeostasis of telomere length;

-temporal activation or inactivation of telomerase in stem-like cells of highly regenerative tissues of hemopoietic and immune system, skin, intestine, which have increased, though limited, proliferative potential. Telomerase is activated in these tissues in case of necessity, when the cells are active and commence fast division;

-mechanism of complete telomerase inactivation in cells reaching the state of terminal differentiation (somatic cells).

Regulation of telomerase activity in the course of cell cycle Telomeres are synthesized during DNA replication in late S-phase in the majority of studied organisms [64-66]. Therefore, the dividing cell does not require active telomerase in the course of the whole cell cycle but during telomere synthesis only. In fact, telomerase activity increases significantly at early stages of S-phase in yeasts [67], during the activation of human lymphocytes [68], in Arabidopsis [69]. The dependence of telomerase activity on the phase of cell cycle was shown best in tobacco BY-2 culture cells, which are well submitted to synchronization. Active telomerase was not detected in the synchronized BY-2 cells during all stages of cell cycle, except for early stage of S-phase [70, 71].

Telomerase activity in S-phase is induced by cytokines in human organisms [72] and by auxin in plants [70, 71]. One of possible mechanisms of telomerase activation in S-phase is transregulation of TERT transcription. In plants, the regulator of cell cycle - E2F1 transcription factor - activates expression of TERT [69], the promoter of which contains a binding site for E2F1. Some controversial data regarding the influence of E2F on human telomerase activity have been reported $[73,74]$.

On the other hand, telomere heterochromatin is remodeled dynamically during cell cycle, protecting telomeres and inhibiting telomerase in the course of all stages of cell cycle, except for S-phase, as it was shown in yeasts. Yeast telomeric protein Rif2 is dissociated from DNA in S-phase, and therefore, cancels the inhibition of telomerase [75]. The results obtained in yeasts were also shown to have the dependence of telomerase binding to telomere on cell cycle. Telomerase catalytic subunit of Est2P yeast is not bound with telomere in G1-phase at the absence of protein-binding protein $\mathrm{Ku}$, and its association with telomeric DNA is weakened at the late stage of S-phase, which is foreseen by the role of $\mathrm{Ku}$ protein in the regulation of telomerase binding to telomere in the course of cell cycle [76]. Ku protein is one of NHEJ (Non-Homologous End-Joining) components [77] and it takes an active part in DNA reparation. It can bind both one- and double-chain disruptions of any of DNA regions. Ku was foreseen to inhibit the degradation and recombination of telomeric repeats on telomeres [78]. Another telomere-binding protein TRF1 was shown to associate with telomeres and to dissociate at its output in extracts of Xenopus laevis eggs, which were at the stage of mitosis [79]. The determining factor of TRF1 binding to telomeric DNA turned out to be its phosphorylation by Polo-like kinase, which also regulates telomerase DNA conformation in the course of cell cycle.

Protein component of telomerase holocomplex of Estlp yeasts which may serve as the bridge molecule between telomere-binding protein of $\mathrm{Cdc} 13$ in yeast 
and the telomerase catalytic nucleus, bridging the connection between them [80], is bound to telomerase before the late stage of S-phase, while Est2p is associated with telomerase throughout the whole cell cycle [81]. On the basis of these results, the model, according to which yeasts telomerase is constantly bound with telomerase in inactive form, and therefore, is constituent of telomeric heterochromatin, was proposed.

In its turn, telomeric heterochromatin remains in tightly condensed condition, additionally creating the obstacle on the way of telomerase to telomere, throughout the cell cycle, except for the S-phase though. In the S-phase telomeric heterochromatin is remodeled, ensuring the access for telomere to telomerase (Fig. 2). At the same time the telomerase is activated, perhaps, due to binding to Est1p and Cdc13, as it was proposed by Zakian et al.

Similar telomere remodeling in the course of cell cycle is possible to occur in human [82]. The proposed model foresees that the telomeric DNA is presented as T-loop, where G-rich overhang is protected from access of telomerase during G1- and G2-phases of cell cycle, when telomeres are not replicated. Nbs1 protein [83], as a part of MRX (Mre11/Rad50/Nbs1) complex, is bound with single strand telomeric DNA in the S-phase. It is possible that Nbs1 causes untwisting of telomeric T-loop, which makes the end of telomeric DNA accessible to telomerase. One more protein, Pot1, which binds single strand DNA of telomeric overhang, plays an important role in regulation of access of telomerase to telomere. The activity of telomerase was revealed to depend on Pot1 localization on the 3 '-end of single strand DNA [84]. Telomerase is incapable of extending telomere in the case when Pot1 is associated with the last repeat of telomeric DNA and its activity is increased significantly, if the protein is bound at a position one telomeric repeat before the 3 '-end, leaving an 8-nucleotide 3'-tail [84].

The use of GFP-TERT-constructions in the primary cell lines of human skin fibroblast revealed the localization of TERT in the nucleolus and its release to the nucleoplasm during telomere replication at the late stages of S-phase [85]. In tumour and transformed cells, complete release of nucleolus from TERT was observed, and vice versa the ionising radiation resulted in reassociation of telomerase with the nucleolus in both primary and transformed cells. It is possible that in human cells the regulation of telomerase activity during cell cycle takes place by the means of its isolation from telomeres in the nucleolus and telomerase release to nucleoplasm only during telomere replication at S-phase (Fig. 2).

The localization of RNA-component of telomerase changes in the process of cell cycle. As it has recently become known TR is localized in nucleoplasmic Cajal bodies $[86,87]$ in the interphase, which were shown to associate with telomeres for 10-40 min during S-phase. The mentioned fact testifies that Cajal bodies are capable of delivering TR to telomere during S-phase and their functions are possible to be interplayed with synthesis of telomeres.

It has been also revealed recently that TERT influences the level of expression and localization of D cyclin (key cell cycle regulator) [88]. TERT expression decrease in some cancer cells resulted in decrease of D cyclin expression level as well as in its disappearance from nucleoplasm, though it was detected in insignificant quantity in cytoplasm. TERT did not change the expression of A1, B1, and E1 cyclins. The activation of cyclin D gene is interrelated to the activation of Ras, Raf, and Akt kinases [89], which serve as the regulators of telomerase activity. This fact shows that telomerase is one of the links of cell cycle regulatory chain.

Therefore, telomerase synthesis of telomeres is cell cycle regulated and includes the transportation of basic components of telomerase to telomere from the nucleolus and Cajal bodies, the modulation of telomerase access to telomere as a result of structural modification of the latter, and the regulation of telomerase activity by the cell regulatory network.

Regulation of telomerase work in order to provide the homeostasis of telomere length Telomere length homeostasis in telomerase-positive cells is achieved due to balancing the processes of loss of telomere repeats as a result of underreplication and/or nucleolytic processing as well as their replenishment due to telomerase synthesis. It has been known for a long time that the latter is regulated by telomere length in accordance to the feedback principle [10]. Therefore, telomerase "works" predominantly on the shortest 

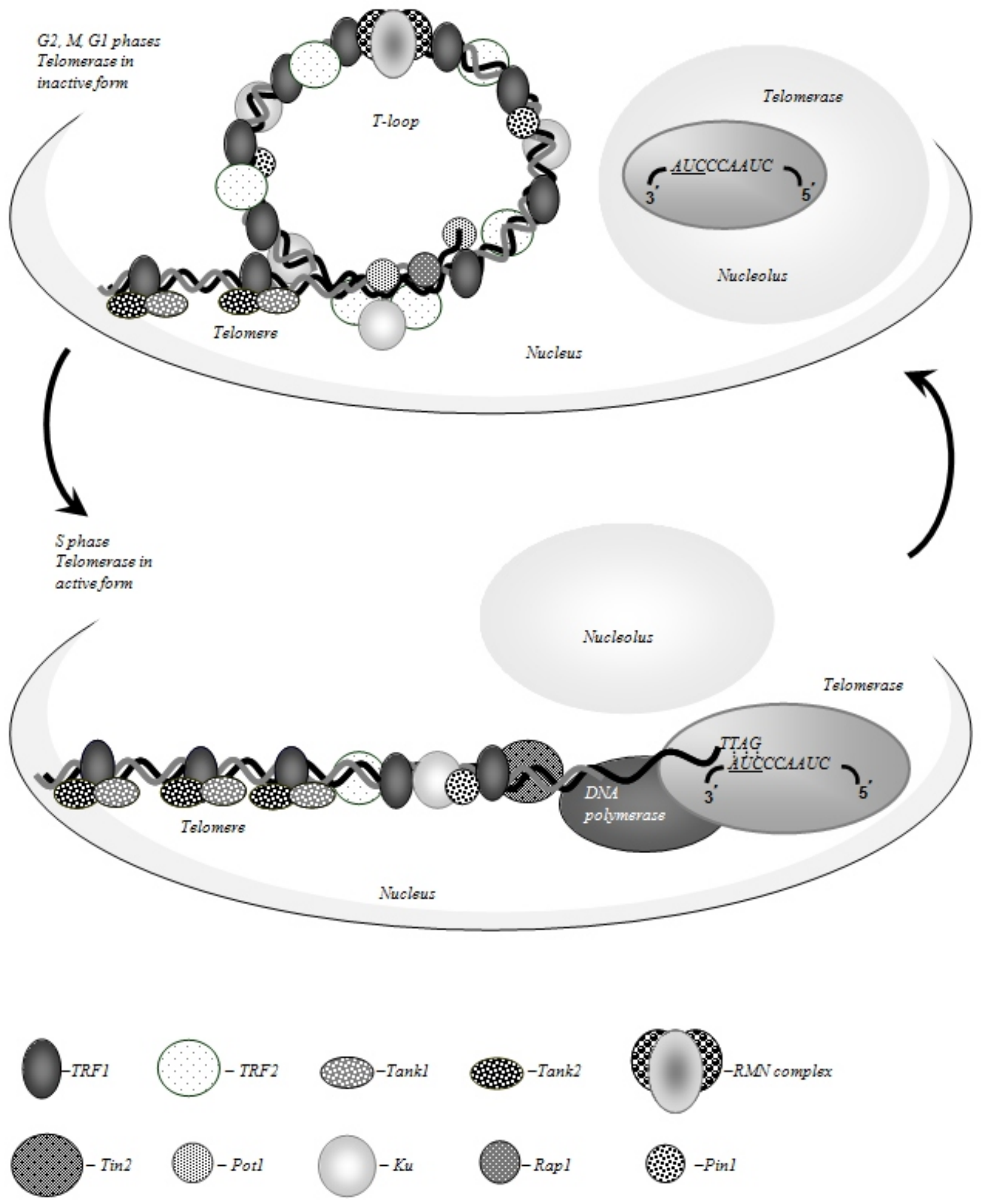

Fig.2. Cell-cycle dependent regulation of telomerase access to telomere in human cells 
telomere in mice [90] and yeasts [91]. Similarly, the expression of limited quantity of telomerase in human fibroblast cells results in extending short telomeres first of all [92]. Such regulation of telomerase activity is achieved due to coordinated work of various genes products. Several dozens of genes which are capable of regulating telomere length have already been discovered. Several groups may be distinguished among them: genes capable of regulating telomerase activity, stability of telomerase holocomplex, and telomerase access to telomere.

As it was shown in yeasts, telomere length at the presence of active telomerase may be regulated by telomere proteins that prevent telomerase binding to telomeric G-rich overhang [11]. In order to provide telomerase access to telomere, free telomere overhang has to be available, i.e. telomere has to be "open". When necessary length of telomere is reached, telomere-binding protein Rap1, as well as associated with it proteins Rif1 and Rif2, "close" the telomere by isolating telomere end. D- and T-loops are this "closed" state of telomerase. Thereafter, telomere is incapable of synthesizing and is shortened gradually at each cell division to the length, insufficient for maintaining "closed" state by the proteins anymore and it passes to state "open" to telomerase. Some proteins of telomeric heterochromatin in yeast turned out to be positive regulators of telomere length. Cdc13 assists in creating telomere-synthesizing machine, binding telomerase to telomere, as a result of direct protein-protein interaction. DNA polymerase I/primase complex also belongs to this machine, and was shown to be physically bound with telomerase [93]. Mutations of polymerase I or primase result in telomere synthesis disordering, which shows the necessity of coordinated synthesis of complementary C-rich chain for the correct synthesis of telomeres [94].

Human TERT gene is localized on the short arm of the 5th chromosome at the distance of $2 \mathrm{MB}$ from telomeric heterochromatin, which provides the possibility of epigenetic regulation of TERT expression depending on the length and/or telomere condition. Such regulation is performed by telomeric heterochromatin and is called "telomeric position effect". It was studied first in yeasts [40] and then later it was discovered in humans [95]. Besides, the telomere length is modulated by methylation of histone proteins of telomeric nucleosomes at constant telomerase activity [42]. Gene hTERT (human TERT) was shown to be localized in both telomerase-negative and telomerase-positive cells in tightly condensed region with at least 100000 b.p., resistant to nuclease influence [96]. hTERT transcription is associated with the appearance of some sites, supersensitive to DNAase I i.e. several minor ones and one main site, located near the site of the initial transcription. In telomerase-negative cells the inhibition of histone deacetylase by trichostatine A resulted in opening the chromatin domain, which contains $h T E R T$ gene, as well as in its transcription increase [96].

The evidences regarding significant complexity of the mechanism providing telomere length homeostasis, which telomerase is also involved to, have been recently obtained as a result of full-scale screening of yeasts mutations, which lead to different kinds of changes in telomere length [97]. The authors analyzed 4852 viable haploid yeast strains, every one of which carried one deletion of open reading frame, and they revealed 173 genes which cause alternate deviations of telomere length. Their functions can be divided into several following categories: first of all, the genes involved in regulation of telomerase activity (e.g. $E S T$, EST2, EST3, TLC1, Ku70, Ku80, Pif1, and of MRX complex); genes providing the stability of telomerase components, for example, telomerase RNA TLC1 (Sm proteins, and MTR 10); genes regulating telomeric heterochromatin, defining either replication or protection of chromosome ends (i.e. Cdc13, Stn1, Ten1, Rap1, Rif1, Rif2, Mec) [97, 98].

Besides, among the genes, the mutations of which result in telomere length deviations there are some which perform other functions which seemingly have nothing to do with telomere length regulation. The largest groups are those involved in vesicular traffic (30 genes), in ribosome function and translation (13 genes), and 10 mitochondrial genes. The interrelation between these genes and telomere activity regulation becomes clear from the screen built by Edmonds et al. [99] using OSPREY software, which is accessible via internet (http://biodata.mshri.on.ca/osprey) [100]. For instance, gene which encodes protein VPS9 is involved in vesicular trafficking and is genetically associated with 
genes, whose products play a role in silencing, and thus can play a direct or indirect role in telomere length regulation [99].

Similar results were obtained in the study on large-scale changes in transcription of yeast Saccharomyces cerevisiae genes as a response to deletion of telomerase RNA-component of TLC1 in yeasts, where the length of telomere was incapable of remaining at the proper level [101]. The transcriptions of almost 6200 open reading frames of $S$. cerevisiae were analyzed in each of nine passages. Approximately 650 open reading frames which changed two or more times in one of the passages at least were revealed. There were genes among them which were involved in protein synthesis, energy processes, reactions to external stress factors, protein folding, cell wall maintenance, carbohydrate and phosphate synthesis, RNA processing and nucleotide synthesis. The functions of almost $1 / 3$ of genes remain unknown yet. In case of telomerase deletion the expression of genes involved in DNA damage and external stresses response was disrupted. Besides, the transcription increase of a large group of genes, responsible for energy processes in mitochondrias, was revealed. And finally, the group of genes, the expression of which was a unique reaction to telomerase deletion, was determined. There were also some genes among them which participated in biogenesis of ribosomes and/or RNA processing [101].

Such regulation in multicellular organisms may be much more complicated as the telomere length in them is regulated depending on the type of cells and their proliferative capability and telomerase activity regulation is tightly bound with the mechanisms of differentiation, regeneration, etc., which are rather diverse.

Regulation of telomerase activity in the process of cell differentiation Telomerase activity depends significantly on the differentiation of human cells [6]. Telomerase was shown to be inverse dependent on the state of differentiation of immortalized and human cancer cells in vitro $[102,103]$. And vice versa the differentiation induction in immortalized mice cell lines did not result in the inhibition of telomerase, which may be explained by fundamentally different mechanisms of telomerase activity regulation in mice, which remains active in various somatic cells [102]. However, in some mice tissues (brain, muscles, heart, stomach) telomerase is also inactivated at the cells reaching the state of terminal differentiation [6], which allows using mice as model organism in order to study mechanisms of telomerase regulation at the differentiation of some cells.

Both hTERT and hTR are necessary for reconstitution of enzymatic activity of human telomerase in vitro [58]. Nevertheless, many works show that transcription of hTERT represents the rate limiting step of telomerase expression [12]. Meanwhile hTR is expressed in both stem and somatic cells, hTERT expression is to some extend correlated with the change of telomerase activity in differentiation processes and is not detected in somatic cells [12]. Besides, ectopic expression of hTERT is enough for restoring of telomerase activity in vitro in many telomerase-negative cell lines [103, 104]. Epigenetic regulation is considered to be the basic regulation mechanism of hTERT expression as the expression of genes in general, including the differentiation processes $[105,106]$.

hTERT promoter does not have any traditional TATA or CAAT boxes but does have multiple $\mathrm{CpG}$ islands, capable of methylation $[107,108]$. This feature and the presence of binding sites for methylation-sensitive transcription factors within the hTERT core promoter, suggests a possible role for methylation in the regulation of hTERT gene expression. There are rather controversial data in regards of dependence of telomerase activity on hTERT promoter methylation status. hTERT promoter was methylated in telomerase-negative fibroblast cell line [109], which indicates the silence of methylated hTERT gene [110]. The methylation of TERT promoter increased telomerase activity in some cases [111], in other cases telomerase activity was decreased [110], or it had no influence at all [112]. Perhaps, such contradiction may be explained by the fact that different binding sites of transcription factors could be methylated in the aforementioned works. The methylation of promoter may both activate and repress hTERT transcription, depending on what binding site is methylated, i.e. activator or repressor one. Liu et al.'s work [113] demonstrated synergistic involvement of 
DNA methylation and deacetylation of histones in order to inhibit hTERT promoter activity at different stages of some types of differentiating cells.

hTERT regulatory region is of approximately $2 \mathrm{MB}$, it contains multiple binding sites of transcription factors [114]. There are two E-boxes among them, which are the places of competitive binding of transcription factor $c-M y c$, which activates the transcription of hTERT as well as repressor Mad [12]. The significant number of transcription factors, which regulate the expression of hTERT, has already been identified, and their number grows constantly $[12,115]$.

The decrease in telomerase activity during differentiation is accompanied by the decrease of mTERT (mouse TERT) expression level in muscular tissues of mice as well as in human somatic cells [116]. The authors showed that binding of transcription factors Sp1, Sp3, and c-Myc with three cis-elements influenced the level of mTERT gene transcription during muscular tissue differentiation in inverse dependence, while MyoD, the mediator of differentiation in muscular tissue, does not interact with mTERT promoter [116]. Nevertheless, MyoD may modulate indirectly the promoter activity inhibiting gene expression of transcriptional factors $\mathrm{Sp} 1$ and $\mathrm{Sp} 3$ [117]. Another transcriptional factor WT1, which has binding site in TERT promoter and inhibits TERT expression, is considered to be tissue-specific and it functions in specific tissues (e.g. spleen, gonads, and kidneys) [118].

There is no information on telomere heterochromatin differences in human cells with different stage of differentiation and consequently with different hTERT expression level. TERT modification is possible to form an additional barrier on the way of telomerase to telomere in somatic cells. For instance, in such a way it takes place in telomerase-negative tobacco cells, which have already reached the stage of terminal differentiation. The proteins associated with telomeres [119] were capable of inhibiting telomerase of tobacco and Silene latifolia, which points out inhibition of telomerase in plant somatic cells at the level of telomeric heterochromatin.

Telomerase activity may be regulated during the processes of differentiation by means of alternative splicing of TERT transcripts. Several splicing forms of
hTERT have been reported [120-124]. Alternative hTERT splicing was shown to reveal tissue specific nature and therefore can not be accidental, but most likely to regulate the level of functionally active telomerase in the cell [125]. All splicing hTERT forms were found to be inactive. One of them, hTERT $\alpha$, was shown to be capable of functioning as dominant-negative inhibitor of telomerase function, which may be possibly conditioned by its capability to bind all available hTR and, therefore, to prevent dimerization of hTERT functional form or its binding with other components of telomerase holocomplex [122].

Smith et al. revealed a rather unexpected interrelation between telomerase and proliferative capacity of cells [126]. He showed that telomerase influences the proliferative state, not only stabilizing telomeres, but also influencing the expression of growth-promoting genes. Ectopic hTERT expression in human mammary epithelial cells increased their growth ability, accompanied by significant changes in gene expression. The authors studied the expression almost 7000 genes at the level of transcription. As a response to ectopic expression of hTERT, 154 genes increased and 92 decreased their transcription. The first group included epidermal growth factor receptor (EGFR) and fibroblast growth factor, in particular [126].

Though many issues about the regulation mechanisms of telomerase activity throughout the process of organism's development, differentiation of cells and terminal desactivation of telomerase in somatic cells remain unknown, having extrapolated the commonly known data, it is possible to foresee these mechanisms being multiple and having both common and specific features for different types of differentiated tissues.

\section{Regulation of telomerase activity in stem-like} cells Contrary to somatic cells, the active telomerase was revealed in the stem-like cells of hemopoietic and immune systems, epidermis, and intestine, however, its activity was lower than in cells of germ line [127]. In this type of cells, telomerase is activated by cytokine stimulation at the stage of entering cell cycle and its activity is correlated with proliferative capability of cells [128]. Though, juvenile lymphocytes do not possess noticeable telomerase activity, a rather 


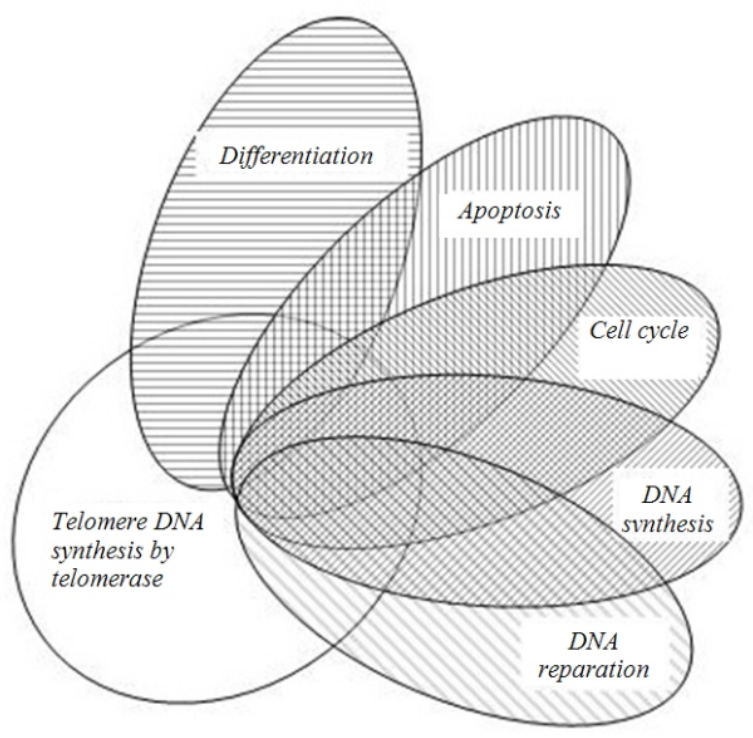

Fig.3. Schematic outline of telomerase place in cell regulatory network

significant level of hTERT transcription is detected in them and in T-cells as well $[129,130]$. The stimulation of lymphocytes is accompanied by a significant phosphorylation of TERT, translocation of TERT subunit out of cytoplasm to the nucleus, and increase of telomerase activity level.

The results presented above indicate the importance of hTERT phosphorylation in flexible regulation of intercellular localization of telomerase and its activity and testify in favor of Aisner et al.'s hypothesis [131], according to which hTERT is located in cytoplasm of unstimulated cells in inactive non-phosphorylated form. hTERT is phosphorylated at the stimulation of lymphocytes, which possibly increases its translocation to the nucleus, i.e. assisting the construction of active telomerase holocomplex.

One more testimony to the aforementioned hypothesis is the data on the role in determining the localization of telomerase played by one more factor i.e. the proteins of 14-3-3 family, which are the co-factors of phosphorylation by serine/threonine kinases of some signaling proteins [132]. In one of the recent works of Seimiya et al. [133] 14-3-3 family proteins were shown to bind TERT as well as determine its nuclear localization, preventing active export of telomerase out of the nucleus and therefore assisting the activation of telomerase. Inactivation of both copies of $14-3-3 \sigma$ gene in telomerase-positive cells resulted in shortening of telomeres, increased the frequency of telomeric fusions and terminal non-reciprocal translocations [134].

TERT was demonstrated to be phosphorylated at specific serine/threonine and tyrosine residues [131]. Telomerase activity increased under protein kinase $\mathrm{C}$ (PKC) activation in mononuclear cells of peripheral blood [135]. There are about 10 isoforms of PKC belonging to a big family of phospholipid-dependent kinases, which take part in cell growth regulation, differentiation of cells, oncogenesis [136]. PKC $\alpha$ was shown to increase telomerase activity in human breast cancer cells [137] and $\mathrm{PKC} \zeta$ was shown to increase it in human nasopharyngeal cancer cells [138]. Various forms of PKC kinases may possibly regulate telomerase activity in different types of cells at different physiological conditions.

There are good reasons to consider serine/threonine protein kinase Akt being capable of phosphorylating TERT as well [139, 140]. Telomerase reverse transcriptase has two possible sites of Akt protein kinase phosphorylation, which is capable of increasing telomerase activity both in vitro [139] and in vivo [140]. Since Akt kinase is a key factor of signaling pathway of phosphatidyl inositol-3-kinase, then telomerase activation of TERT phosphorylation is explained by the mechanism of stimulating proliferation of cells by phosphatidyl inositol-3-kinase and their survival [141].

Regardless of the presence of active telomerase, the length of telomere in stem-like cells decreases with the age, though slower than in somatic cells. Ectopic expression of telomerase in $\mathrm{CD} 34^{+}$and $\mathrm{C}_{133^{+}}$blood cells resulted in almost 10-time increase of telomerase activity, which led to telomere elongation by 600 b.p. [142]. Similar increase in telomerase activity in somatic cells of fibroblast resulted in the telomere elongation by 2000 b.p. Moreover, a significant increase in telomerase activity due to ectopic expression of telomerase did not prevent telomeres from shortening in serumless culture [142].

Such difference in telomerase processivity in stem-like and somatic cells is possibly explained by additional mechanisms of telomerase length control, e.g. due to control of telomerase access to telomere by telomere-binding proteins. Therefore, numerous data regarding regulation of telomerase activity, which were 
obtained on various objects with different specific physiological aspects up to now, testify in favor of the fact that the mentioned process is rather complicated, multi-staged, interrelated, and well-coordinated.

Telomerase activity is regulated at all the levels of enzyme expression and function beginning from its biosynthesis to alternative splicing of transcripts of catalytic subunits both at the level of its posttranslational modifications and at the level of telomerase-telomere binding. Besides, telomerase is active in multimeric complex only [143]. Therefore, it is possible that the temporary change in telomerase activity may also be achieved at the expense of regulation telomerase holocomplex formation [144] or as a result of change of expression of its other protein subunits. For instance, telomerase holocomplex subunits, chaperons HSP90 and p23 are necessary for reconstruction of telomerase activity complex out of recombinant TERT and TR [145].

The main telomerase function is the maintenance of telomeres, which provide the integrity and stability of chromosomes and therefore play an important role in proper functioning of the cell. Thus, the regulation of telomerase activity should be tightly interrelated with other biochemical processes of the cell, e.g. cell cycle regulation, differentiation, apoptosis, DNA synthesis and reparation [146] (Fig.3). Regulatory networks of telomerase as well as their relation to the regulation of other processes are not studied well-enough nowadays. Re-expression of enzymes of the system was shown to take place in the same order in which they enter biosynthesis in well-studied system of amino acid biosynthesis in Escherichia coli [147]. Such coordination is to take place in case of telomerase activity regulation.

Having analyzed numerous experimental results it is possible to foresee telomerase to be one of the links of single, complicated and interrelated chain of elements and events in the cell, which provide the performance of all cell programs.

\section{Л. В. Порублева}

Молекулярные механизмы регуляции теломеразной активности

Резюме

Теломераза - особый рибонуклеопротеин синтезируюший теломеры, которые расположенны на концах линейных хромосом, и обеспечивают иелостность и стабильность хромосомного аппарата. Теломера- за активна в стволовых клетках и практически не детектируется в соматических клетках. Активность теломеразы регулируется в проиессе клеточного циила, при дифференцировке клеток и коррелирует с их пролиферативной способностью. К тому же, в теломеразо-положительных клетках зародышевой линии она регулируется с ияелью обеспечить гомеостаз длины теломер. Последние исследования глобального изменения экспрессии генов в теломерных и теломеразных мутантах свидетельствуют о том, что механизмы регуляции теломеразы очень сложные, многоуровневые, взаимопереплетающиеся $и$ в высокой степени скоординированные. В настоящем обзоре рассматриваются современные данные о регуляции активности теломеразы во время клеточного ичкла, в ходе дифференцииации, а также механизмы обеспечения гомеостаза длины теломер у человека и некоторых модельных организмов.

Ключевые слова: теломераза, теломера, регуляторные механизмы, дифференцировка, клеточный циикл, пролиферативный потенциал, гомеостаз.

\section{REFERENCES:}

1. McClintock B. The behavior in successive nuclear divisions of a chromosome broken at meiosis // Proc. Natl. Acad. Sci. USA. - 1939. -25 . - P. 405-416.

2. Olovnikov A.M. [Principle of marginotomy in template synthesis of polynucleotides]//Dokl Akad Nauk SSSR.- 1971. - 201, № 6. - P. 1496-1498. [Russian]

3. Blackburn E.H., Gall J. A tandemly repeated sequence at the termini of the extrachromosomal ribosomal RNA genes in Tetrahymena // J. Mol. Biol. - 1978. - 120, N 1. - P. 33-53.

4. Greider C.W., Blackburn E.H. Identification of a specific telomere terminal transferase activity in Tetrahymena extracts // Cell. - 1985. 43, N 2, pt 1 . - P. 405-413.

5. Dokudovskaya S.S., Petrov A.V., Dontsova O.A., Bogdanov A.A.. Telomerase is an unusual RNA-containing enzyme. A review// Biochemistry (Mosc). - 1997. - 62, N 11. - P.1206-1215.

6. Forsyth N.R., Wright W.E., Shay J.W. Telomerase and differentiation in multicellular organisms: Turn it off, turn it on, and turn it off again // Differentiation. - 2002. -69, N (4-5). - P. 188-197.

7. De Lange T. Protection of mammalian telomeres // Oncogene. -2002. - 21, N 4. - P. 532-540.

8. Harley C.B. Telomerase is not an oncogene// Oncogene. -2002 . -21 . N 4. - P.494-502.

9. Harrington L. Biochemical aspects of telomerase function // Cancer Letters - 2003. - 194, N 2. - P. 139-154.

10. Smogorzewska A., de Lange T. Regulation of telomerase by telomeric proteins // Annu. Rev. Biochem. - 2004. - 73. - P.177-208.

11. Evans S.K., Lundblad V. Positive and negative regulation of telomerase access to the telomere // J. Cell Sci. - 2000. - 113, N 19. P. 3357-3364

12. Poole J.C., Andrews L.G., Tollefsbol T.O. Activity, function, and gene regulation of the catalytic subunit of telomerase (TERT) // Gene. - 2001. - 269, N 1-2. - P.1-12

13. Cong Y.-S, Wright W.E., Shay J.W. Human telomerase and its regulation // Microbiol. Mol. Biol. Rev. - 2002. - 66, N 3. P.407-425.

14. Mergny J.-L., Riou J.-F., Mailliet P., Teulade-Fichou M.-P., Gilson E. Natural and pharmacological regulators of telomerase // Nucleic Acids Res. - 2002. - 30, N 4, - P.839-865.

15. McEachern M.J., Krauskopf A., Blackburn E. H. Telomeres and their control // Annu. Rev. Genet. - 2000. - 34. - P.331-358.

16. Vega L.R., Mateyak M.K., Zakian V.A. Getting to the end: telomerase access in yeast and humans // Nature Rev. Mol. Cell Biol. - 2003. - 4, N 12. - P.948-959.

17. Ducrest A.L., Szutorisz H., Lingner J., Nabholz M. Regulation of the human telomerase reverse transcriptase gene // Oncogene. - 2002. 21, N 4. - P. 541-552. 
18. Brunori M., Luciano P., Gilson E., Geli V. The telomerase cycle: normal and pathological aspects // J. Mol. Med. - 2005. - 83, N 4. P.244-257.

19. Blackburn E.H. Telomeres and telomerase: their mechanisms of action and the effects of altering their functions // FEBS Lett. - 2005. -579, N 4. - P. 859-862.

20. Hug N., Lingner J. Telomere length homeostasis // Chromosoma. 2006. Jun 2; [Epub ahead of print]

21. Autexier C., Lue N.F. The structure and function of telomerase reverse transcriptase // Annu. Rev. Biochem. - 2006. - 75. P.493-517.

22. Chung H.K., Cheong C., Song J., Lee H.-W. Extratelomeric functions of telomerase // Curr. Mol. Med.- 2005. - 5, N 2. - P.233-241.

23. Hathcock K.S., Chiang Y.J., Hodes R.J. In vivo regulation of telomerase activity and telomere length // Immunol. Rev. - 2005. 205. - P.104-113.

24. Collins K. The biogenesis and regulation of telomerase holoenzymes // Nat. Rev. Mol. Cell Biol. - 2006. - 7, N 7. - 484-494.

25. Lundblad V. DNA ends: maintenance of chromosome termini versus repair of double strand breaks // Mutat. Res. $-2000 .-451$, N 1-2. - P. $227-240$.

26. Rhodes D., Fairall L., Simonsson T., Court R., Chapman L. Telomere architecture // EMBO reports. - 2002. - 3, N 12. - P. 1139-1145.

27. Kuimov A.N. Polypeptide components of telomere nucleoprotein complex //Biochemistry (Mosc). - 2004. - 69, N 2. - P.117-129.

28. Pryde F.E, Louis E.J. Saccharomyces cerevisiae telomeres. A review // Biochemistry (Mosc) - 1997. - 62, N 11. - P.1232-1241.

29. Kurenova E. V., Mason J. M. Telomere functions. A Review // Biochemistry (Mosc).- 1997. - 62, N 11. - P.1242-1253.

30. Richards E.J., Ausubel F.M. Isolation of a higher eukaryotic telomere from Arabidopsis thaliana // Cell. - 1988. - 53, N 1 - P. 127- 136.

31. Shampay J., Szostak J.W., Blackburn E.H. DNA sequences of telomeres maintained in yeast // Nature. - 1984. - 310, N 5973. - P. $154-157$

32. Pich U., Fuchs J., Schubert I. How do Alliaceae stabilize their chromosome ends in the absence of TTTAGGG sequences? // Chromosome Res. - 1996. - 4, N 3. - P. 207-213.

33. Levis R.W., Ganesan R., Houtchens K., Tolar L.A., Sheen F. Transposons in place of telomeric repeats at a Drosophila telomere // Cell. - 1993. - 75, N 6. - P. 1083-1093.

34. Adams S.P., LeitchI.J., Bennett M.D., Leitch A.R. Aloe L. - A second family without (TTTAGGG)n telomeres // Chromosoma. 2000. - 109, N 3. - P. 201-205.

35. Griffith J.D., Comeau L., Rosenfield S., Stansel R.M., Bianchi A., Moss H. de Lange,T. Mammalian telomeres end in a large duplex loop // Cell. - 1999. - 97, N 4. - P. 503-514.

36. Grandin N., Damon C., Charbonneau M. Ten1 functions in telomere end protection and length regulation in association with Stn1 and Cdc13 // EMBO J. - 2001. -20, N 5. - P. 1173-1183.

37. van Steensel B., Smogorzewska A., de Lange T. TRF2 protects human telomeres from end-to-end fusions // Cell. - 1998. - 92, N 3.P. 401-413.

38. Lingner J., Cech T.R. Purification of telomerase from Euplotes aediculatus: requirement of a primer 3' overhang // Proc. Natl. Acad. Sci. U S A. - 1996. - 93, N 20. - P. 10712-10717.

39. Bianchi A., Smith S., Chong L., Elias P., de Lange T. TRF1 is a dimer and bends telomeric DNA // EMBO J. - 1997. - 16, N 7. - P. 1785-1794.

40. Lowell J.E., Pillus L. Telomere tales: chromatin, telomerase and telomere function in Saccharomyces cerevisiae // Cell. Mol. Life Sci. - 1998. - 54, N 1. - P. 32-49.

41. Blasko M. Telomere epigenetics: a higher-order control of telomere length in mammalian cells // Carcinogenesis. $-2004 .-25$, N 7. - P. 1083-1087.

42. Garcia-Cao M., O’Sullivan R., Peters A.H., Jenuwein T., Blasco M.A. Epigenetic regulation of telomere length in mammalian cells by the Suv39h1 and Suv39h2 histone methyltransferases // Nat. Genet. 2004. - 36, N 1. - P. 94-99.
43. Loayza D., De Lange T. POT1 as a terminal transducer of TRF1 telomere length control // Nature. - 2003. - 424, N 6943. - P. 1013-1018.

44. De Lange T. T-loops and the origin of telomeres // Nat. Rev. Mol. Cell. Biol. - 2004. - 5, N 4. - P. 323-329.

45. Zijlmans J.M., Martens U.M., Poon S.S., Raap A.K., Tanke H.J., Ward R.K., Lansdorp P.M. Telomeres in the mouse have large inter-chromosomal variations in the number of T2AG3 repeats // Proc. Natl. Acad. Sci. USA. - 1997. - 94, N 14. - P. 7423-7428.

46. Huffman K.E., Levene S.D., Tesmer V.M., Shay J.W., Wright W.E. Telomere shortening is proportional to the size of the 3y G-rich telomeric overhang // J. Biol. Chem. - 2000. - 275, N 26. - P. 19719-19722.

47. Zou Y., Sfeir A., Gryaznov S.M., Shay J.W., Wright W.E. Does a sentinel or a subset of short telomeres determine replicative senescence? // Mol. Biol. Cell. - 2004. - 15, N 8. - P. 3709 - 3718.

48. Hemann M.T., Strong M.A., Hao L.Y., Greider C.W. The shortest telomere, not average telomere length, is critical for cell viability and chromosome stability // Cell. - 2001. - 107, N 1. - P.67-77.

49. Kim S.-H., Kaminker P., Campisi J. Telomeres, aging and cancer: In search of a happy ending // Oncogene. - 2002. - 21, N 4. - P. 503-511.

50. Skulachev V.P. Phenoptosis: programmed death of an organism // Biochemistry (Mosc) - 1999. - 64, N 12. - P.1418-1426.

51. Lingner J., Hughes T.R., Shevchenko A., Mann M., Lundblad V., Cech T.R. Reverse transcriptase motifs in the catalytic subunit of telomerase // Science. - 1997. - 276, N 5312. - P. 561-567.

52. Nakamura T.M., Morin G.B., Chapman K.B., Weinrich S.L., Andrews W.H., Lingner J., Harley C.B., Cech T.R. Telomerase catalytic subunit homologs from fission yeast and human // Science. 1997. - 277, N 5328. - P.955-959.

53. Bachand F., Autexier C. Functional regions of human telomerase reverse transcriptase and human telomerase RNA required for telomerase activity and RNA-protein interactions // Mol. Cell. Biol. - 2001. - 21, N 5. - P. 1888-1897.

54. Bryan T.M., Goodrich K.J., Cech T.R. Telomerase RNA bound by protein motifs specific to telomerase reverse transcriptase // Mol. Cell. - 2000. - 6, N 2. - P. 493-499.

55. Etheridge K.T., Banik S.S., Armbruster B.N., Zhu Y., Terns R.M., Terns M.P., Counter C.M. The nucleolar localization domain of the catalytic subunit of human telomerase // J. Biol. Chem. - 2002. - 277, N 27. - P. 24764-24770.

56. Chen J.L., Blasco M.A., Greider C.W. Secondary structure of vertebrate telomerase RNA // Cell. - 2000. - 100, N 5. - P.503-514.

57. Blackburn E.H. The end of the (DNA) line // Nat. Struct. Biol. - 2000. - 7, N 10. - P. 847-850.

58. Weinrich S.L., Pruzan R., Ma L., Ouellette M., Tesmer V.M., Holt S.E., Bodnar A.G., Lichtsteiner S., Kim N.W., Trager J.B., Taylor R.D., Carlos R., Andrews W.H., Wright W.E., Shay J.W., Harley C.B., Morin G.B. Reconstitution of human telomerase with the template RNA component hTR and the catalytic protein subunit hTRT // Nat. Genet. - 1997. - 17, N 4. - P.498-502.

59. Chang J.T.C., Chen Y.L., Yang H.T., Chen C.Y., Cheng A.J. Differential regulation of telomerase activity by six telomerase subunits // Eur. J. Biochem. - 2002. - 269, N 14. - P. 3442-3450.

60. Harrington L., McPhail T., Mar V., Zhou W., Oulton R., Bass M.B., Arruda I., Robinson M.O. A mammalian telomerase-associated protein // Science. - 1997. - 275, N 5302. - P. 973-977.

61. Holt S.E., Aisner D.L., Baur J., Tesmer V.M., Dy M., Ouellette M., Trager J.B., Morin G.B., Toft D.O., Shay J.W. et al. Functional requirement of p23 and Hsp90 in telomerase complexes // Genes Dev. - 1999. - 13, N 7. - P. 817-826.

62. Wright W.E., Piatyszek M.A., Rainey W.E., Byrd W., Shay J.W. Telomerase activity in human germline and embryonic tissues and cells // Dev. Genet. - 1996. - 18, N 2. - P. 173-179.

63. McKnight T.D., Fitzgerald M.S., Shippen D.E. Plant telomeres and telomerases. A review // Biochemistry (Mosc) - 1997. - 62, N 11. P.1224-1231. 
64. McCarroll R., Fangman W.L. Time of replication of yeast centromeres and telomeres // Cell. - 1988. - 54, N 4. - P. 505-513.

65. Ferguson B.M., Brewer B.J., Reynolds A.E., Fangman W.L. A yeast origin of replication is activated late in S phase // Cell. - 1991. - 65, N 3. - P. 507-515.

66. Wright W.E., Tesmer V.M., Liao M.L., Shay J.W. Normal human telomeres are not late replicating // Exp. Cell Res. - 1999. - 251, N 2. - P.492-499.

67. Marcand S., Brevet V., Mann C., Gilson E. Cell cycle restriction of telomere elongation // Curr. Biol. - 2000. - 10, N 8. - P.487-490.

68. Yamada O., Motoji T., Mizoguchi H. Up-regulation of telomerase activity in human lymphocytes // Biochim. Biophys. Acta. - 1996. 1314, N 3, - P.260-266.

69. Ramirez-Parra E., Frondt C., Gutierrez C. A genome-wide identification of E2F-regulated genes in Arabidopsis // Plant J. 2003. - 33, N 4. - P. 801-811.

70. Tamura K., Liu H., Takahashi H. Auxin induction of cell cycle regulated activity of tobacco telomerase // J. Biol. Chem. - 1999. 274 , N 30. - P. 20997-21002.

71. Yang S.W., Jin E., Chung I.K., Kim W.T. Cell cycle-dependent regulation of telomerase activity by auxin, abscisic acid and protein phosphorylation in tobacco BY-2 suspension culture cells // Plant J. 2002. - 29, N 5. - P. 617-626.

72. Engelhardt M., Kumar R., Albanell J., Pettengell R., Han W., Moore M.A. Telomerase regulation, cell cycle, and telomere stability in primitive hematopoietic cells // Blood. - 1997. - 90, N 1. P.182-193.

73. Crowe D.L., Nguyen D.C. Rb and E2F-1 regulate telomerase activity in human cancer cells // Biochim. Biophys. Acta. -2001. - 1518, N 1. - P. 1-16.

74. Crowe D.L., Nguyen D.C., Tsang K.J., Kyo S. E2F-1 represses transcription of the human telomerase reverse transcriptase gene // Nucleic Acids Res. - 2001. - 29, N 13. - P. 2789-2794.

75. Smith C.D., Smith D.L., DeRisi J.L., Blackburn E.H. Telomeric protein distributions and remodeling through the cell cycle in Saccharomyces cerevisiae // Mol. Biol. Cell. - 2003. - 14, N 2. - P. $556-570$.

76. Fisher T.S., Taggart A.K., Zakian V.A. Cell cycle-dependent regulation of yeast telomerase by $\mathrm{Ku} / /$ Nat. Struct. Mol. Biol. - 2004. - 11, N 12. - P. 1198-1205.

77. Gravel S., Larrivee M., Labrecque P., Wellinger R.J. Yeast Ku as a regulator of chromosomal DNA end structure. // Science. - 1998. 280, N 5364. - P. 741-744.

78. Baumann P., Cech T.R. Protection of telomeres by the Ku protein in fission yeast. // Mol. Biol. Cell. - 2000. - 11, N 10. - P. 3265-3275.

79. Nishiyama A., Muraki K., SaitoM., OhsumiK., Kishimoto T., Ishikawa1F. Cell-cycle- dependent Xenopus TRF1 recruitment to telomere chromatin regulated by Polo-like kinase // EMBO J. - 2006 -25, N 3. - P.575-584

80. Evans S.K., Lundblad V. Est1 and $\mathrm{Cdc} 13$ as comediators of telomerase access // Science. - 1999. - 286, N 5437. - P.117-120.

81. Taggart A.K.P., Teng S.-C., Zakian V.A. Est1p as a cell cycle-regulated activator of telomere-bound telomerase // Science. 2002. - 297, N 5583. - P.1023-1026.

82. Riha K., Shippen D.E. Telomere structure, function and maintenance in Arabidopsis // Chromosome Res. - 2003. - 11, N 3. - P. 263-275.

83. Zhu X.D., Kuster B., Mann M., Petrini J.H., de Lange T. Cell-cycle-regulated association of RAD50/MRE11/NBS1 with TRF2 and human telomeres // Nat. Genet. $-2000 .-25$, N 3. - P. 347-352.

84. Lei M., Zaug A.J., Podell E.R., Cech T.R. Switching human telomerase on and off with hPOT1 Protein in Vitro // J. Biol. Chem. 2005. - 280, N 21. - P. 20449-20456.

85. Wong J.M., Kusdra L., Collins K. Subnuclear shuttling of human telomerase induced by transformation and DNA damage // Nat. Cell Biol. - 2002. - 4, N 9. - P. 731-736.
86. Tomlinson R.L., Ziegler T.D., Supakornde T.j, Terns R.M., Terns M.P. Cell cycle-regulated trafficking of human telomerase to telomeres // Moll. Biol. Cell. - 2006. - 17, N 2. - P.955-965.

87. Jady B.E., Richard P., Bertrand E., Kiss T. Cell cycle-dependent recruitment of telomerase RNA and Cajal bodies to human telomeres // Moll. Biol. Cell. - 2006. - 17, N2. - P. 944-954.

88. Jagadeesh S., Banerjee P.P. Telomerase reverse transcriptase regulates the expression of a key cell cycle regulator, cyclin D1// Biochem. Biophys. Res. Commun. - 2006. - 347, N 3.-P. 774-780.

89. Fu M., Wang C., Li Z., Sakamaki T., Pestell R.G. Cyclin D1: normal and abnormal functions // Endocrinology. - 2004. - 145, N12 P.5439-5447.

90. Samper E., Flores J.M., Blasco M.A. Restoration of telomerase activity rescues chromosomal instability and premature aging in Terc-/- mice with short telomeres // EMBO Rep. - 2001. - 2, N 9. - P. 800-807.

91. Teixeira M.T., Arneric M., Sperisen P., Lingner J. Telomere length homeostasis is achieved via a switch between telomerase-extendible and -nonextendible states // Cell. - 2004. - 117, N 3. - P. 323-335.

92. Ouellette M.M., Liao M., Herbert B.S., Johnson M., Holt S.E., Liss H.S., Shay J.W., Wright W.E. Subsenescent telomere lengths in fibroblasts immortalized by limiting amounts of telomerase // J. Biol. Chem. - 2000. - 275, N 14. - P.10072-10076.

93. Dahlen M., Sunnerhagen P., Wang T.S.-F. Replication proteins influence the maintenance of telomere length and telomerase protein stability // Mol. Cell Biol. - 2003. - 23, N 9. - P. 3031-3042.

94. Martin A.A., Dionne I., Wellinger R.J., Holm C. The function of DNA polymerase a at telomeric $\mathrm{G}$ tails is important for telomere homeostasis // Mol. Cell Biol. - 2000. - 20, N 3. - P. 786-796.

95. Baur J. A., Zou Y., Shay J. W., Wright W. E. Telomere position effect in human cells // Science - 2001. - 292, N 5524. - P.2075-2077.

96. Wang S., Zhu J. The hTERT gene is embedded in a nuclease-resistant chromatin domain / J. Biol. Chem. - 2004. - 279, N 53. - P. 55401-55410.

97. Askree S.H., Yehuda T., Smolikov S., Gurevich R., Hawk J., Coker C., Krauskopf A., Kupiec M., McEachern M. J. A genome-wide screen for Saccharomyces cerevisiae deletion mutants that affect telomere length // Proc. Natl. Acad. Sci.USA. - 2004. - 101, N 23. - P. 8658-8663.

98. Blackburn E.H. Switching and signaling at the telomere // Cell. 2001. - 106, N 6. - P. 661-673.

99. Edmonds D., Breitkreutz B.-J., Harrington L. A genome-wide telomere screen in yeast: and short of it all // Proc. Natl. Acad. Sci. USA. - 2004. - 101, N 26. - P. 9515-9516.

100. Breitkreutz B.J., Stark C., Tyers M. Osprey: a network visualization system // Genome Biol. - 2003. - 4, N 3. - R22.

101. Nautiyal S., DeRisi J.L., Blackburn E.H. The genome-wide expression response to telomerase deletion in Saccharomyces cerevisiae // Proc. Natl. Acad. Sci. USA. - 2002. - 99, N 14. P.9316-9321.

102. Bestilny L.J., Brown C.B., Miura Y., Robertson L.D., Riabowol K.T. Selective inhibition of telomerase activity during terminal differentiation of immortal cell lines // Cancer Research. - 1996. - 56, N 16. - P.3796-3802.

103. Counter C.M., Meyerson M., Eaton E.N., Ellisen L.W., Caddle S.D., Haber D.A., Weinberg R.A. Telomerase activity is restored in human cells by ectopic expression of TERT (hEST2), catalytic subunit of telomerase // Oncogene. -1998. - 16, N 9. - P.1217-1222.

104. Vaziri H., Benchimol S. Reconstitution of telomerase activity in normal human cells leads to elongation of telomeres and extended replicative life span // Curr. Biol. - 1998. - 8, N 5. - P. 279-282.

105. Rupp R.A.W., Singhal N., Veenstra G.J.C. When the embryonic genome flexes its muscles: Chromatin and myogenic transcription regulation // Eur. J. Biochem. - 2002. - 269, N 9. - P. 2294-2299

106. Rasmussen T.P. Embryonic stem cell differentiation: a chromatin perspective // Reprod.Biol. Endocrinol. - 2003. - 1, N 1. - P.100. 
107. Cong Y.-S., Wen J., Bacchetti S. The human telomerase catalytic subunit TERT: organization of the gene and characterization of the promoter // Hum. Mol. Genet. - 1999. - 8, N 1. - P. 137-142.

108. Horikawa I., Cable P.L., Afshari C., Barrett J.C. Cloning and characterization of the promoter region of human telomerase reverse transcriptase gene // Cancer Res. - 1999. - 59, N 1. - P. 826-830.

109. Devereux T.R., Horikawa I., Anna C.H., Annab L.A., Afshari C.A., Barrett J.C. DNA methylation analysis of the promoter region of the human telomerase reverse transcriptase (TERT) gene // Cancer Research. - 1999. - 59, N 24. - P. 6087-6090.

110. Lopatina N.G., Poole J.C., Saldanha S.N., Hansen N.J., Key J.S., Pita M.A., Andrews L.G., Tollefsbol T.O. Control mechanisms in the regulation of telomerase reverse transcriptase expression in differentiating human teratocarcinoma cells // Biochem. Biophys. Res. Commun. - 2003. - 306, N 3. - P. 650-659.

111. Guilleret I., Yan P., Grange F., Braunschweig R., Bosman F.T., Benhattar J. Hypermethylation of the human telomerase catalytic subunit (TERT) gene correlates with telomerase activity // Int. J. Cancer. - 2002. - 101, N 4. - P. 335-341.

112. Guilleret I., Yan P., Guillou L., Braunschweig R., Coindre J.-M., Benhattar J. The human telomerase RNA gene (hTERC) is regulated during carcinogenesis but is not dependent on DNA methylation // Carcinogenesis. - 2002. - 23, N 12. - P. 2025-2030.

113. Liu L., Saldanha S.N., Pate M.S., Andrews L.G., Tollefsbol T.O. Epigenetic regulation of human telomerase reverse transcriptase promoter activity during cellular differentiation Genes Chromosomes Cancer. - 2004. - 41, N 1. - P. 26-37.

114. Takakura M., Kyo S., Kanaya T., Hirano H., Takeda J., Yutsudo M., Inoue $\mathrm{M}$. Cloning of human telomerase reverse transcriptase gene promoter and identification of proximal core promoter essential for transcriptional activation of TERT in immortalized and cancer cells // Cancer Res. - 1999. - 59, N 4. - P. 551-559.

115. Ducrest A.L., Szutorisz H., Lingner J., Nabholz M. Regulation of the human telomerase reverse transcriptase gene // Oncogene. - 2002. 21, N 4. - P. 541-552.

116. Nozawa K., Maehara K., Isobe K.-I. Mechanism for the reduction of telomerase expression during muscle cell differentiation // J. Biol. Chem. - 2001. - 276, N 25. - P. 22016-22023.

117. Fandos C., Sanchez-Feutrie M., Santalucia T., Vinals F., Cadefau J., Guma A., Cusso R., Kaliman P., Canicio J., Palacin M., A. Zorzano. GLUT1 glucose transporter gene transcription is repressed by Sp3. Evidence for a regulatory role of Sp3 during myogenesis // J. Mol. Biol. - 1999. - 294, N 1. - P. 103-119.

118. Oh S., Song Y., Yim J., Kim T. K. The Wilms' Tumor 1 Tumor Suppressor Gene Represses Transcription of the Human Telomerase Reverse Transcriptase Gene // J. Biol. Chem. - 1999. - 274, N 52. - P. 37473 - 37478.

119. Fulneckova J., Fajkus J. Inhibition of plant telomerase by telomere-binding proteins from nuclei of telomerase-negative tissues // FEBS Lett. - 2000. - 467, N 2-3 - P. 305-310.

120. Kilian A., Bowtell D.D., Abud H.E., Hime G.R., Venter D.J., Keese P.K., Duncan E.L., Reddel R.R., Jefferson R.A. Isolation of a candidate human telomerase catalytic subunit gene, which reveals complex splicing patterns in different cell types // Hum. Mol. Genet. - 1997. - 6, N 12. - P. 2011-2019.

121. Ulaner G.A., Hu J.F., Vu T.H., Giudice L.C., Hoffman A.R. Telomerase activity in human development is regulated by human telomerase reverse transcriptase (TERT) transcription and by alternate splicing of TERT transcripts // Cancer Res. $-1998 .-58, \mathrm{~N}$ 18. - P. 4168-4172.

122. Colgin L.M., Wilkinson C., Englezou A., Kilian A., Robinson M.O., Reddel R.R. The TERTб splice variant is a dominant negative inhibitor of telomerase activity // Neoplasia. -2000 . - 2, N 5. - P. 426-432.

123. Yi X., White D.M., Aisner D.L., Baur J.A., Wright W.E., Shay J.W. An alternate splicing variant of the human telomerase catalytic subunit inhibits telomerase activity // Neoplasia. -2000 . - 2, N 5. - P. 433-440.
124. Ulaner G.A., Hu J.F., Vu T.H., Oruganti H., Giudice L.C., Hoffman A.R. . Regulation of telomerase by alternate splicing of human telomerase reverse transcriptase (TERT) in normal and neoplastic ovary, endometrium and myometrium // Int. J. Cancer. - 2000. - 85, N 3. - P. 330-335.

125. Ulaner G.A., Hu J.F., Vu T.H., Giudice L.C., Hoffman A.R. Tissue-specific alternate splicing of human telomerase reverse transcriptase (TERT) influences telomere lengths during human development // Int. J. Cancer. - 2001. - 91, N 5. - P. 644-649.

126. Smith L.L., Coller H.A., Roberts J.M. Telomerase modulates expression of growth-controlling genes and enhances cell proliferation // Nat. Cell. Biol. - 2003. - 5, N 5. - P. 474-479.

127. Elwood N. Telomere biology of human hematopoietic stem cells // Cancer Control. - 2004. - 11, N2. - P.77-85.

128. Weng N.P., Granger L., Hodes R.J. Telomere lengthening and telomerase activation during human B cell differentiation // Proc. Natl. Acad. Sci. U S A. - 1997. - 94, N 20. - P.10827-10832.

129. Liu K., Schoonmaker M.M., Levine B.L., June C.H., Hodes R.J., Weng N.P. Constitutive and regulated expression of telomerase reverse transcriptase (TERT) in human lymphocytes // Proc. Natl. Acad. Sci. U S A. - 1999. - 96, N 9. - P.5147-5152.

130. Liu K.,Hodes R.J., Weng N. Cutting edge: telomerase activation in human $\mathrm{T}$ lymphocytes does not require increase in telomerase reverse transcriptase (TERT) protein but is associated with TERT phosphorylation and nuclear translocation // J Immunol. - 2001. 166, N 8. - P.4826-30.

131. Aisner D.L., Wright W.E., Shay J.W. Telomerase regulation: not just flipping the switch // Curr. Opin. Genet. Dev. - 2002. - 12, N 1. P.80-85.

132. Tzivion G., Avruch J. 14-3-3 proteins: active cofactors in cellular regulation by serine/threonine phosphorylation // J. Biol. Chem. 2002. - 277, N 5. - P.3061-3064.

133. Seimiya H., Sawada H., Muramatsu Y., Shimizu M., Ohko K., Yamane K., Tsuruo T. Involvement of 14-3-3 proteins in nuclear localization of telomerase // EMBO J. - 2000. - 19, N 11. P.2652-2661.

134. Dhar S., Squire J.A., Hande M.P., Wellinger R.J., Pandita T.K. Inactivation of 14-3-3sigma influences telomere behavior and ionizing radiation-induced chromosomal instability // Mol. Cell Biol. -2000 . - 20, N 20. - P.7764-7772.

135. Bodnar A.G., Kim N.W., Effros R.B., Chiu C.P. Mechanism of telomerase induction during T cell activation // Exp. Cell Res. -1996. -228, N 1. - P.58-64.

136. Liu J.P. Protein kinase C and its substrates // Mol. Cell Endocrinol. 1996. - 116, N 1. - P. 1-29.

137. Li H., Zhao L., Yang Z., Funder J.W., Liu J.P. Telomerase is controlled by protein kinase Calpha in human breast cancer cells // J. Biol. Chem. - 1998. - 273, N 50. - P. 33436-33442.

138. Yu C.C., Lo S.C., Wang T.C. Telomerase is regulated by protein kinase C-zeta in human nasopharyngeal cancer cells // Biochem. J. 2001. - 355, Pt 2. - P.459-464.

139. Breitschopf K., Zeiher A. M., Dimmeler S. Pro-atherogenic factors induce telomerase inactivation in endothelial cells through an Akt dependent mechanism // FEBS Lett. - 2001. - 493, N 1. - P.21-25.

140. Kang S.S., Kwon T., Kwon D.Y., Do S.I. Akt protein kinase enhances human telomerase activity through phosphorylation of telomerase reverse transcriptase subunit // J. Biol. Chem. - 1999. 274, N 19. - P.13085-13090.

141. Lawlor M.A., Alessi D.R. PKB/Akt: a key mediator of cell proliferation, survival and insulin responses? // J.Cell Sci. - 2001. 114, Pt 16. - P.2903-2910.

142. Zimmermann S., Glaser S., Ketteler R., Waller C.F., Klingmuller U., Martens U.M. Effects of telomerase modulation in human hematopoietic progenitor cells // Stem Cells. -2004 . - 22, N 5. P.741-749.

143. Arai K., Masutomi K., Khurts S., Kaneko S., Kobayashi K., Murakami S. Two independent regions of human telomerase reverse 
transcriptase are important for its oligomerization and telomerase activity // J. Biol. Chem. - 2002. - 277, N 10. - P.8538 - 8544.

144. Collins K. The biogenesis and regulation of telomerase holoenzymes // Nat Rev. Mol. Cell Biol. - 2006. - 7, N 7. - 484-494.

145. Keppler B.R., Grady A.T., Jarstfer M.B. The biochemical role of the heat shock protein 90 chaperone complex in establishing human telomerase activity //J. Biol. Chem. - 2006. - 281, N29. P.19840-19848.
146. d'Adda di Fagagna F., Teo S.-H., Jackson S.P. Functional links between telomeres and proteins of the DNA-damage response // Genes Dev.- 2004. - 18, N15 - P.1781-1799.

Надійшла до рде 577214.625 